\title{
A "missing link" for the Macdonald and Arago hotspots
}

\author{
L. BUFF ${ }^{1}$, M.G. JACKSON ${ }^{1}$, K. KONRAD ${ }^{2}$, M. BIZIMIS ${ }^{3}$, \\ A.A. KopPers ${ }^{2}$, A. PrICE ${ }^{4}$, E. Rose-KogA ${ }^{5}$, J. G \\ KONTER $^{6}$, J. BLUSZTAJN ${ }^{7}$ \\ ${ }^{1}$ U. California Santa Barbara, Santa Barbara, CA 93106 \\ ${ }^{2}$ CEOAS, Oregon State U., USA \\ ${ }^{3}$ SEOE, U. South Carolina, Columbia, SC 29208 \\ ${ }^{4}$ Los Alamos National Laboratory, NM 87545 \\ ${ }^{5} \mathrm{LMV}$, Université Clermont Auvergne, France \\ ${ }^{6} \mathrm{U}$. of Hawaii, Manoa, Honolulu, HI 96822 \\ ${ }^{7}$ Woods Hole Institute of Oceanography, Woods Hole, MA \\ 02543
}

The Cook-Austral Volcanic Lineament (CAVL) has been characterized as multiple overlapping hotspot tracks generated by at least two mantle plumes, including the Arago and Macdonald plumes (anchored by the eponymous seamounts) [1]. The majority of seamounts in the CAVL fall into Macdonald-type or Arago-type geochemical groups, within which an age progression emerges for each hotspot track. Absolute plate motion models for the Pacific plate suggest the Macdonald seamount chain may extend past Samoa, where it bends contemporaneously with the HawaiiEmperor Bend (HEB) at $\sim 50 \mathrm{Ma}$, and extends upward into the Tokelau chain [2]. While the northern Tokelau chain aligns well with Macdonald-type CAVL volcanoes in geochronology and composition, a critical lack of data around the $\sim 50 \mathrm{Ma}$ bend has hindered the confirmation of continued Macdonald plume activity in the Tokelau chain [3].

Here, we present major and trace element, and isotopic, data for seamounts Moki, Malulu, Papatua, Dino, and Rose atoll. Sample locations are west of the CAVL and, with the exception of Papatua, all sample geochemisty falls within established isotope space defined by Macdonald- type CAVL seamounts. The more northern location of Moki is of particular interest as it is likely at or above the bend in the Macdonald hotspot track at $\sim 50$ Ma postulated by Wessel \& Kroenke (2008) as matching the HEB [2]. We argue that seamounts Moki, Malulu, D, and the Rose atoll are products of the Macdonald mantle plume and extend the Macdonald hotspot track an additional $\sim 1,000 \mathrm{~km}$, past the Samoa hotspot track and into the Tokelau islands. This model is being further tested through ${ }^{40} \mathrm{Ar} /{ }^{39} \mathrm{Ar}$ age determinations of recovered lava flows from these seamounts.

[1] Chauvel (1997) Chemical Geology 139 125-143. [2] Wessel \& Kroenke (2008) Journal of Geophysical Research 113 B06101. [3] Konter et al. (2008) EPSL 275 285-295. 